\title{
The Study of Customer Satisfaction, Customer Trust and Switching Barriers on Customer Retention in Malaysia Hypermarkets
}

\author{
Seiedeh Nasrin Danesh \\ Faculty of Management and Information Technology, UCSI University \\ Jalan Menara Gading, UCSI Heights, 56000 Kuala Lumpur, Malaysia \\ Tel: 60-17-313-2730Ｅ-mail: Danesh.nasrin@yahoo.com
}

Saeid Ahmadi Nasab

Faculty of Management and Information Technology, UCSI University

Jalan Menara Gading, UCSI Heights, 56000 Kuala Lumpur, Malaysia

Tel: 60-13-292-8962 E-mail: nashelsae@yahoo.com

Kwek Choon Ling (Corresponding author)

Faculty of Management and Information Technology, UCSI University

Jalan Menara Gading, UCSI Heights, 56000 Kuala Lumpur, Malaysia

Tel: 60-16-688-6248Ｅ-mail: kwekcl@ucsi.edu.my

\author{
Received: December 24, 2011 Accepted: January 29, $2012 \quad$ Published: April 1, 2012 \\ doi:10.5539/ijbm.v7n7p141 \\ URL: http://dx.doi.org/10.5539/ijbm.v7n7p141
}

\begin{abstract}
The objective of this research is to examine the direct relationship of customer satisfaction, customer trust and switching barriers on customer retention as well as the relationship between customer satisfaction and trust. This descriptive research was conducted within the context of the hypermarkets in Kuala Lumpur, the capital city of Malaysia. There were 150 set of questionnaires being distributed as the mean of data collection and analyzed by Statistical Package for Social Sciences (SPSS) version 17. This research confirmed the significant positive relationship of customer satisfaction, trust and switching barriers on overall customer retention in Malaysia hypermarkets. It is also confirmed that customer satisfaction has a direct relationship with customer trust in Malaysia hypermarkets.
\end{abstract}

Keywords: Customer satisfaction, Customer trust, Switching barriers and customer retention

\section{Introduction}

The topic of customer retention is well covered in the extant literature due to its important in influencing the organization's financial profitability. Various factors have contributed to the customer retention, such as customer trust, customer satisfaction and switching barriers (Ranaweera and Prabhu, 2003). The current literature only evaluates the direct impacts of customer trust, customer satisfaction and switching barriers on customer retention. However, there is a lack of extant literature to evaluate the inter-relationships among the customer trust, customer satisfaction, switching barriers and customer retention. With this research gap in mind, this research would like to study the impacts of customer trust, customer satisfaction and switching barriers on customer retention as well as the relationship between customer satisfaction and customer trust in the Malaysia hypermarket context. The underlining tested conceptual model used in this research was adapted from Ranaweera and Prabhu (2003). The tested hypotheses will be evaluated through quantitative research in the form of survey among all the walked-in customers of the Giant and Carrefour hypermarkets within Kuala Lumpur. Questionnaires will be distributed in the survey. The study will be concluded with the data findings and recommendations will be suggested. 


\section{Literature Review}

\subsection{Customer Retention}

Customer retention is one of the most important indicators of the customer satisfaction. From the literature review, it is discovered that customer satisfaction has traditionally been regarded as a fundamental determinant of long-term customer behaviour (Oliver, 1980; Yi, 1990). The more satisfied customers are, the greater is their customer retention (Anderson and Sullivam, 1993; Fornell, 1992; Lee et al., 2001; Ranaweera and Prabhu, 2003). Cronin and Taylor (1992) and Patterson et al. (1997) found that customer satisfaction has a significant positive effect on repurchase intention in a range of services. Day et al., (1988) stated that client customer satisfaction is unquestionably the key determinant in retaining current clients in professional services. Kotler (1994) stated that the key to customer retention is customer satisfaction.

Customer retention is defined as the future propensity of a customer to stay with the service provider (Ranaweera and Prabhu, 2003). While some scholars have used the term "future behavioral intentions" to describe the concept of customer retention (Zeithaml et al., 1996). This study will follow the literature of Cronin et al. (2000, p.204) who treat "behavioral intentions" and "customer retention" as synonymous constructs.

In the past, the key to understand the power of a corporation to retain customers was thought to lie in the measurement of customer satisfaction. However, customer satisfaction is not the only required factor to retain customer with the firms and cannot insure customer support for long time (Jones and Sasser, 1995). While customer satisfaction is one of the most important factors, customer trust and switching barriers both independently and in relation to each other have influence to the level of the customer retention. Thus, this research aims to study the antecedent relationship between the customer satisfaction, customer trust and switching barriers on the customer retention as well as the relationship between customer satisfaction and customer trust in Malaysia hypermarkets context. Figure1 indicates the purposed conceptual framework for this research.

\subsection{Customer Satisfaction}

Customer satisfaction is defined as the "summary psychological state resulting when the emotion surrounding disconfirmed expectations is coupled with the consumers prior feelings about the consumption experience" (Oliver, 1981, p 27). Thus, Hansemark and Albinsson (2004) argue that "satisfaction is an overall customer attitude towards a service provider, or an emotional reaction to the difference between what customers expect and what they receive, regarding the fulfillment of some need, goal or desire".

Nowadays the effect of customer satisfaction on customer retention plays more complex role than the past days and than initially thought (Mittal and Kamakura, 2001; Oliver, 1999). The literature review recognized customer satisfaction has traditionally been regarded as a most important characteristic of long-term customer behavior (Oliver, 1980; Yi, 1990). The more satisfied customers are, the greater is their customer retention (Anderson and Sullivam, 1993; Fornell, 1992; Lee et al., 2001; Ranaweera and Prabhu, 2003). In a study by Cronin and Taylor (1992) and Patterson et al. (1997), it is recognized that customer satisfaction has a meaningful and positive effect on the repurchasing of a customer in a special classification of services. It is expressed by a team of researchers that customer satisfaction is an indisputable manner in determining the degree of customer retention for the current buyers in the professional services (Day et al., 1988). It is also reiterated by Day et al. (1988) and Kotler (1994) that the customer satisfaction is a significant factor to customer retention. Therefore, this research would like to evaluate the relationship between customer satisfaction and customer retention via the first hypothesis. The first hypothesis is presented as follow:

H1: Customer satisfaction has a direct positive effect on customer retention.

\subsection{Customer Trust}

Mayer et al. (1995) define trust as "the willingness of a party to be vulnerable to the actions of another party based on the expectation that the other will perform a particular action important to the trustor, irrespective of the ability to monitor or control that other party". Service providers, in some cases, may not be able to retain their satisfied customers (Heskett et al., 1994; Schneider and Bowen, 1999) because the customer satisfaction itself alone cannot ensure long term commitment of the customer to any service provider. Instead, the service providers should think to the other factors beyond customer satisfaction, such as customer trust, to retain their customers (Hart and Johnson, 1999). This argument is supported by Morgan and Hunt (1994). Morgan and Hunt (1994) assert that the target of the firms is to develop customer trust beyond customer satisfaction to retain their customers in a long term period. In other words, customer trust is likely to be a strong driver of customer retention (Ranaweera and Prabhu, 2003). Thus, this research would like to evaluate the relationship between 
customer trust and customer retention (H2) and the relationship between customer satisfaction and customer retention (H4). Therefore, the second and forth hypotheses are presented as follow:

\section{H2. Customer trust has a direct positive effect on customer retention}

H4: Customer satisfaction has a positive effect on customer trust

\subsection{Switching Barriers}

Perceived switching barriers is defined as the consumer's assessment of the resources and opportunities needed to perform the switching act, or alternatively, the constraints that prevent the switching act (Bansal and Taylor, 1999; Ranaweera and Prabhu, 2003).

Keaveney's (1995) critical incident study was one of the first to examine switching barriers as the determinant of customer switching behaviour. Subsequently, Gremler and Brown (1996) used in-depth interviews to develop a model that included switching costs as an antecedent of customer loyalty.

Study showed that while you invest in time, money and your effort, all of these items define switching costs which in result make your perception as difficulty to switch. Researches also show that switching barriers may have both main and interaction effects on customer retention (Gremler and Brown, 1996; Bansal and Taylor, 1999; Lee et al., 2001). As a consequence, when switching barriers are high, service firms may continue to retain customers even if they are not highly satisfied. While the aim of most firms is to offer 100 per cent customer satisfaction, this is often not feasible. For example, the American customer satisfaction index for the second quarter of the year 2002 (ACSI Index, 2002) shows that the overall customer satisfaction index for the cross-industry is only 73 percent (Ranaweera and Prabhu, 2003). In this context, identifying alternative means of retaining customers, such as through switching barriers, is particularly useful. Therefore, Ranaweera and Prabhu (2003) argue that examining the role of switching barriers could help service firms find a cost-effective alternative to achieve customer satisfaction.

As it is already mentioned that the switching costs deemed as the investment of time, money and effort. As in the customers' perception, these switching costs make difficulty for buyers to switch and change from one retailer to others (Gremler and Brown, 1996). Given that the time and effort required switching are perceived to be important switching barriers, service providers may therefore wish to focus on service features that increase switching costs without necessarily creating absolute barriers to switching. Indeed, researcher suggests that an ideal way for firms to prevent customer resentment is to create switching barriers that also add value to the service (Ranaweera, C. and Prabhu, J., 2003). Therefore, this research would like to evaluate the relationship between switching barriers and customer trust (H3). Therefore, the third hypothesis will be presented as follow:

H3. Switching barriers has a positive effect on customer retention

\section{Research Method}

\subsection{Research Design}

This research adopted positivism approach because this approach; (1) allowed the researcher to search for truths of the observation and by using the empirical evidence through hypothetico- deductive method; and (2) many researches and observations on the customer retention had been conducted and the extant literature was well developed (Jankowicz, 2005). The study in this research has clear problem statements, specific hypotheses; therefore the researcher adopted the descriptive research for the research design. The researcher has used quantitative research methodology which is explained this adopted methodology in this chapter. Researcher did not find out the relevant secondary data in related to the title of this study, therefore primary data collection has chosen for this research.

\subsection{Questionnaire Design}

After deciding the adoption of primary data collection, the questionnaire design would be the next step. A questionnaire is a formalized set of questions involving one or more measurement scales designed to collect specified primary data (Shukla, 2008). Regardless of the form of administration, the questionnaire should be administered in a way to determine the information which we need to test hypotheses and support research objectives.

There are three parts in the design of the questionnaire. The first part asked the respondents about their demographic characteristics. The second part detailed the independent and dependent variables that would be tested in the survey.

In measuring the constructs, multi-item scales were used in the questionnaire with adoption from different 
sources of the existing literature. To measure customer satisfaction and customer retention, the items were adopted from (Wong and Mula, 2009; Ranaweera and Prabhu, 2003; Wong, 2011), where else the measurement for customer trust and switching barrier were adopted from Ranaweera and Prabhu (2003). The questionnaire contained structured questions with Likert-type scales. Researchers have applied Likert scale format in this research because the scale was suitable for self-administered survey method (Hair, Bush and Ortinau, 2004). All the items measured in the questionnaire were using a 7-point Likert scale anchored by: $1=$ strongly disagree, $2=$ disagree, $3=$ somewhat disagree, $4=$ neither agree nor disagree, $5=$ somewhat agree, $6=$ agree and $7=$ strongly agree.

\subsection{Sampling}

The target population in this research covered all individual walked-in customers of the Giant and Carrefour hypermarkets. Researcher distributed the questionnaires randomly to the customers of these hypermarkets in Kuala Lumpur, the capital city of Malaysia. The targeted sample size was 150 . Thus, a total of 150 sets of questionnaire were distributed equally across two different hypermarkets (that is, 75 copies of the questionnaire for each hypermarket). Convenience sampling technique was used to select potential respondents in this survey.

\subsection{Administration of Survey}

As part of the research process in this study, the researcher distributed self-administered questionnaires to the customers of the selected hypermarkets and collected all related information which enabled the researcher to analyze and find the relationship of various constructs in related to the topic of this study.

The survey was conducted in the different outlets of the Giant and Carrefour hypermarkets where respondents could return the questionnaires immediately to the researcher. The voluntary nature of the participation was explained verbally as well as being indicated in the survey questionnaire. Potential respondents were invited to complete anonymous survey questionnaires that took approximately 10 minutes of their time to complete.

A total of 150 sets of questionnaires were distributed and 140 usable questionnaires were collected. Out of that, 10 sets of questionnaires were considered unusable because they were incomplete whereby over $25 \%$ of the total questions related to the independent and dependent variables were not answered (Sekaran, 2003). It was assumed that the respondents were either unwilling to cooperate or not serious with the survey. The SPSS software version 17 was used for analyzing the questionnaire. In total, the response rate was 93.33 percent (140/150).

\section{Research Results}

\subsection{Respondents' Demographic Profile}

Part one of the questionnaire is pertaining to the respondents' demographic profile. The respondents' demographic profile in this research was divided into five categories, which were gender, age group and average monthly income level (Ringgit Malaysia), citizenship and marital status. Table 1 shows details of the respondents' demographic profiles.

Based on this survey, the male respondents represented 52.9 percent while the female respondents represented 47.1 percent of the total respondents. According to this survey, the age distributions of the respondents were: (1) Less than 20 years old (50 percent); (2) 21-30 years old (47.1 percent); (3) 31-40 years old (2.1 percent); and (4) above 40 years old ( 0.8 percent).

It is also observed for citizenship category that 55.7 percent of the respondents were Malaysian while the non Malaysian respondents were 44.3 percent. Majority of the respondents were single ( 97.1 percent) while the married respondents accounted only for 2.9 percent.

\subsection{Reliability Test}

One of the test which can ensure the stability and consistency of the measures and help to assess the 'goodness' of a measure is reliability test. Reliability in research relates to the consistency of results over a period of time. A scale is called reliable if it produces consistent results when repeated measurements are made (Hair, et al., 2004). The results from Table 2 indicated that the Cronbach alpha for all the four constructs were well above 0.7 as recommended by Cavana et al. (2001). Cronbach's alpha for the four constructs ranged from the lowest of 0.874 (customer trust) to highest 0.942 (switching barriers). In conclusion, it can clearly be seen that the scores of the Cronbach's alpha for all the constructs used in this research are well more than 0.70 and this confirmed that the measurement scales used for measurement of the constructs were stable and consistent, therefore the reliability of the constructs were confirmed. 


\subsection{Validity Test}

Validity of a scale is defined as the extent to which differences in observed scale scores reflect the true differences among objects on the characteristics being measured (Malhotra, 1996). Validity can be measured by examining through content, criterion and construct validity. Construct validity is divided into two parts namely, convergent and discriminant validity (Hair et al., 2004). Construct validity was adopted in this research as validity measurement and factor analysis was used to measure the construct validity (Cavana, et. al., 2001). Exploratory factor analysis was adopted as a validity test for this research.

The output of the factor analysis showed in the Table 3, the factor analysis was appropriate because the value of Kaiser-Meyer-Olkin (KMO) was 0.840 (between 0.5 and 1.0) and the statistical test for Bartlett test of sphericity was significant $(\mathrm{p}=0.0001$; d.f. $=66)$ for all the correlations within a correlation matrix (at least for some of the constructs). Based on the principal components analysis and VARIMAX procedure in orthogonal rotation that were adopted in the factor analysis, the results showed that the Eigenvalues for all the tested constructs were greater than 1.0 as indicated in Table 3, ranging from the lowest of 1.146 (customer trust) to the highest of 5.561 (switching barriers). In term of convergent validity, the factor loadings for all items within the constructs showed in Table 3 were more than 0.50 . According to Table 3, discriminate validity indicated that all items were allocated according to the different constructs. Therefore, the items were not overlapping and they supported respective constructs.

\subsection{Regression Analyses}

\subsubsection{Multiple Regression Analysis}

Multiple regression analysis is defined as "a statistical technique which analyzes the linear relationships between a dependent variable and multiple independent variables by estimating coefficients for the equation for a straight line" (Hair et. al., 2004, p.578). Multiple regression analysis was carried out to test three pre-determined hypotheses in the study (H1, H2 and H3).

Based on the finding from Table 4 , the $\mathrm{p}$ value of the $\mathrm{t}$-test $(\mathrm{p}=0.015)$ between customer satisfaction and customer retention is less than the alpha value of 0.05 . Therefore, the study concluded that the customer satisfaction is positively related to the customer retention (H1). In addition, the result from Table 4 also indicated that the $\mathrm{p}$ value of the t-test $(\mathrm{p}=0.0001)$ between switching barriers and customer retention is less than the alpha value of 0.05 . Therefore, switching barriers has a positive relationship on customer retention (H3). The results from Table 4 also indicated the $p$ value of the t-test $(p=0.0001)$ between customer trust and customer retention is less than the alpha value of 0.05 . Therefore, Customer trust has a direct positive relationship on customer retention (H2).

Based on the SPSS output, the following multiple regression equation was formed:

$$
\begin{gathered}
\text { Customer Retention }=-0.893+0.179 \text { Customer Satisfaction }+0.397 \text { Customer Trust }+0.257 \text { Switching } \\
\text { Barriers }
\end{gathered}
$$

In conclusion, the values of unstandardized Beta coefficient among the independent variables tested in the hypotheses ranged from the weakest relationship of 0.179 (between customer satisfaction and customer retention) to the strongest relationship of 0.397 (between customer trust and customer retention). It may conclude that the "customer trust" is the most powerful antecedent in affecting the customer retention. Switching barriers with the 0.257 value of unstandardized Beta coefficient ranked the second in terms of importance of antecedents to the customer retention. Based on Table 4, the study also concluded that the change of the customer retention is explained 38.8 percent $\left(\mathrm{r}^{2}=38.8\right.$ percent) by a combination of various independent variables, including customer satisfaction, customer trust and switching barriers.

\subsubsection{Simple Regression Analysis}

The simple regression "is a procedure for deriving a mathematical relationship in the form of an equation, between a single metric dependent or criterion variable and a single metric independent or predictor variable" (Hair et. al., 2006; Malhotra et. al., 2006, p.692). The objective of the simple regression is to find an independent variable that will improve on the baseline prediction (Hair et. al., 2006, p.178). Simple regression analysis was carried out to test the fourth hypothesis. The result of simple regression analysis is presented in Table 5, the $p$ value of the t-test $(\mathrm{p}=0.003)$ between customer satisfaction and customer trust is less than the alpha value of 0.05 . Therefore, it is obvious that there is a positive relationship between the customer satisfaction and customer trust.

Based on the SPSS output, the following simple regression equation was formed: 


\section{Customer Trust $=8.571+0.226$ Customer Satisfaction}

In conclusion, the above simple regression equation indicates that the customer satisfaction is the antecedent of the Customer trust. The value of the unstandardized beta coefficient is 0.226 . Based on Table 5, the study concluded that the change of the customer trust is explained 6.3 percent $\left(r^{2}=6.3\right.$ percent $)$ by customer satisfaction.

\section{Conclusions}

\subsection{Conclusions of Hypotheses}

The research finding of this study confirms that customer satisfaction, customer trust and switching barriers are positively related to the overall customer retention in the Malaysia retail market. In addition, the research finding also concludes that customer satisfaction has a positive effect on customer trust. In conclusion, all the four hypotheses are supported.

\subsection{Implications of Research Findings}

The research findings and contributions have brought some implications to the hypermarket operators. The research findings provide some insights and feedback for the hypermarket's management in drafting managerial strategies on how to increase customer retention. Hypermarket managements need to emphasize on the important of customer trust, switching barriers and customer satisfaction in their strategic business planning in order to enhance the level of customer retention

\subsection{Limitations of Research}

Although the research findings provide some insights to researcher, these findings should be viewed in light of some limitations. To summarize, the limitations associated with the research findings are: (1) This study was adopting judgmental sampling technique method. Thus the result cannot be generalizable. (2) This study was conducted via cross sectional study. Thus, the changes of the customer retention over a period of time cannot be identified.

\subsection{Recommendations for Further Research}

Due to the limitations of this research which is mentioned above, it is recommended that necessary actions should be taken into consideration for further research in order to enhance the study of the customer retention in the presence of the adopted determinants. It is also recommended to adopt probability sampling method and conduct the longitudinal study for the future research.

\section{References}

Anderson, E.W., and Sullivan, M.W. (1993). The antecedents and consequences of customer satisfaction for firms. Marketing Science, Vol. 12 No. 2, pp. 125-43. http://dx.doi.org/10.1287/mksc.12.2.125

Bansal, H.S., and Taylor, S.F. (1999). The service provider switching model (SPSM): A model of consumer switching behaviour in the service industry. Journal of Service Research, Vol. 2 No. 2, pp. 200-18. http://dx.doi.org/10.1177/109467059922007

Cavana, R.Y., Delahaye, B.L., and Sekaran, U. (2001). Applied business research: Qualitative and quantitative methods. John Wiley \& Sons: Queensland.

Cronin, J.J., and Taylor, S.A. (1992). Measuring Service Quality: A Reexamination and Extension. Journal of Marketing, Vol. 56, 55-68. http://dx.doi.org/10.2307/1252296

Cronin, J.J., Brady, M.K., and Hult, G.T.M. (2000). Assessing the effects of quality, value, and customer satisfaction on consumer behavioral intentions in service environments. Journal of Retailing, Vol. 76 No. 2, pp. 193-218. http://dx.doi.org/10.1016/S0022-4359(00)00028-2

Day, E, Denton, LL \& Hickner, JA. (1988). Clients' selection and retention criteria: Some marketing implications for the small CPA firm. Journal of Professional Services Marketing, vol. 3, no. 4, pp. 85-91.

Fornell, C. (1992). A national customer satisfaction barometer: The Swedish experience. Journal of Marketing, Vol. 56, January, pp. 6-21. http://dx.doi.org/10.2307/1252129

Gremler, D.D., and Brown, S.W. (1996). Service loyalty: Its nature, importance, and implications. In Edwardson, B., Brown, S.W. and Johnston, R. (Eds), Advancing Service Quality: A Global Perspective, International Service Quality Association, pp. 171-80.

Hair, J.F., Bush, P.R., and Oftinau, D.J. (2004). Marketing research: within a changing information environment, (2nd edition.). McGraw-Hill: New York. 
Hansemark, O. C., \& Albinson, M. (2004). Customer satisfaction and retention: The experiences of individual employees. Managing Service Quality, 14 (1), pp. 40-57. http://dx.doi.org/10.1108/09604520410513668

Hart, C.W., and Johnson, M.D. (1999). Growing the trust relationship. Marketing Management, Spring, pp. 8-19. Heskett, J.L., Jones, T.O., Loveman, G.W., Sasser, W.E., and Schlesinger, L.A. (1994). Putting the service-profit chain to work. Harvard Business Review, March/April, pp. 164-74.

Jankowicz, AD. (2005). Business research project, (4 ed.). Thomson Learning: London.

Jones, T.O., and Sasser, W.E. (1995). Why satisfied customers defect. Harvard Business Review, November/December, pp. 88-99.

Keaveney, S.M. (1995). Customer switching behavior in service industries: an exploratory study. Journal of Marketing, Vol. 59, pp. 71-82. http://dx.doi.org/10.2307/1252074

Kotler, P (1994). Marketing management: Analysis, planning, implementation, and control, (8th ed.). Prentice-Hall, Inc, New Jersey.

Lee, J., Lee, J., and Feick, L. (2001). The impact of switching costs on the customer satisfaction-loyalty link: mobile phone service in France. Journal of Services Marketing, Vol. 15 No. 1, pp. 35-48. http://dx.doi.org/10.1108/08876040110381463

Malhotra, N. K., I Agarwal, and M. Peterson. (1996). Methodological issues in cross-cultural marketing research. International Marketing Review, vol 13 No.5, pp 7-43. http://dx.doi.org/10.1108/02651339610131379

Malhotra, N., Hall, J., Shaw, M., and Oppenheim, P. (2006). Marketing research: An applied orientation. (3rd edn). Prentice Hall: New South Wales.

Mayer, R. C., Davis, J. H., \& Schoorman, F. D. (1995). An integrative model of organizational trust. The Academy of Management Review, 20(3), 709-734.

Mittal, V \& Kamakura, WA. (2001). Satisfaction, repurchase intent, and repurchase behaviour: Investigating the moderating effect of customer characteristics. Journal of Marketing Research, vol. 38, no. 1, pp. 131-142. http://dx.doi.org/10.1509/jmkr.38.1.131.18832

Morgan, R.M., and Hunt, S.D. (1994). The commitment-trust theory of relationship marketing. Journal of Marketing, Vol. 58, July, pp. 20-38. http://dx.doi.org/10.2307/1252308

Oliver, R.L. (1980). A cognitive model of the antecedents and consequences of satisfaction decisions. Journal of Marketing Research, Vol. XVII, November, pp. 460-9. http://dx.doi.org/10.2307/3150499

Oliver, R.L. (1981). Measurement and evaluation of satisfaction processes in retail setting. Journal of Retailing, vol.57, no.3, pp.25-46.

Patterson, PG, Johnson, LW \& Spreng, RA. (1997). Modeling the determinants of customer satisfaction for business-to-business professional services. Journal of the Academy of Marketing Science, vol. 25, no.1, pp. 4-17. http://dx.doi.org/10.1007/BF02894505

Ranaweera, C., and Prabhu, J. (2003). The influence of satisfaction, trust and switching barriers on customer retention in a continuous purchasing setting. International Journal of Service Industry Management, vol.14, no.4, pp.374-395. http://dx.doi.org/10.1108/09564230310489231

Schneider, B., and Bowen, D. (1999). Understanding customer delight and outrage. Sloan Management Review, Fall, pp. 35-45.

Sekaran, U. (2003). Research methods for business: A skill-building approach, $\left(4^{\text {th }}\right.$ edn. $)$. New York: John Wiley and Sons.

Shukla, p. (2008). Marketing research: An introduction. Frederiksberg, Ventus Publishing ApS.

Wong. C. B. (2011). The influence of customer satisfaction and switching costs on customer retention: Retail internet banking services. Global Economy and Finance Journal, Vol. 4. no. 1. March 2011 pp. 1-18.

Wong. C. B., \& Mula, J. M. (2009). The moderating effect of switching costs on the customer satisfaction-retention link: Retail Internet Banking Service in Hong Kong. IBIMA BUSINESS REVIEW, Volume 2, 2009, pp. 20-28.

Yi, Y. (1990). A critical review of consumer satisfaction. In Zeithaml, V.A. (Ed.), Review of Marketing, American Marketing Association, Chicago, IL, pp. 68-123.

Zeithaml, V.A., Berry, L.L., and Parasuraman, A. (1996). The behavioral consequences of service quality. Journal of Marketing, Vol. 60, April, pp. 31-46. http://dx.doi.org/10.2307/1251929 
Table 1. Respondents' Demographic Profiles

\begin{tabular}{|l|c|c|}
\hline \multicolumn{1}{|c|}{ Profile } & Frequency & Percentage (\%) \\
\hline Gender & & 52.9 \\
Male & 74 & 47.1 \\
Female & 66 & 50 \\
\hline Age & & 47.1 \\
Less than 20 years old & 70 & 2.1 \\
21-30 years old & 66 & 0.8 \\
31-40 years old & 3 & \\
Above 40 years old & 1 & 55.7 \\
\hline Citizenship & & 44.3 \\
Malaysian & 78 & \\
Non Malaysian & 62 & 97.1 \\
\hline Marital Status & 136 & 2.9 \\
Single & 4 & \\
Married & & \\
\hline
\end{tabular}

Source: Developed for this research

Table 2. Reliability of the Constructs

\begin{tabular}{|l|c|}
\hline \multicolumn{1}{|c|}{ Constructs } & Cronbach's Alpha \\
\hline Customer satisfaction & 0.898 \\
\hline Customer Retention & 0.894 \\
\hline Customer Trust & 0.874 \\
\hline Switching Barrier & 0.942 \\
\hline
\end{tabular}

Source: Developed for this research 
Table 3. Validity Test (Factor Analysis)

\begin{tabular}{|c|c|c|c|c|c|c|}
\hline $\begin{array}{c}\text { Number } \\
\text { of } \\
\text { Factors }\end{array}$ & $\begin{array}{l}\text { Factor's } \\
\text { Name }\end{array}$ & Variable & $\begin{array}{c}\text { Factor } \\
\text { Loading }\end{array}$ & $\begin{array}{l}\text { Eigen- } \\
\text { value }\end{array}$ & $\begin{array}{c}\text { Percentage } \\
\text { of Variance } \\
\text { Explained }\end{array}$ & $\begin{array}{l}\text { Cronbach's } \\
\text { Reliability } \\
\text { Coefficients }\end{array}$ \\
\hline F1 & $\begin{array}{l}\text { Customer } \\
\text { Satisfaction }\end{array}$ & $\begin{array}{l}\text { Overall, I am happy with my } \\
\text { hypermarket. } \\
\text { My hypermarket meets my } \\
\text { expectations. } \\
\text { I think I did the right thing when I } \\
\text { chose this hypermarket. }\end{array}$ & $\begin{array}{l}0.920 \\
0.906 \\
0.868\end{array}$ & 2.228 & 21.049 & 0.898 \\
\hline F2 & $\begin{array}{l}\text { Customer } \\
\text { Retention }\end{array}$ & $\begin{array}{l}\text { What do you think are the chances } \\
\text { of you totally terminating your } \\
\text { relationship with your hypermarket } \\
\text { within the next three month? } \\
\text { What do you think are the chances } \\
\text { of you totally terminating your } \\
\text { relationship with your hypermarket } \\
\text { within the next six months? } \\
\text { What do you think are the chances } \\
\text { of you totally terminating your } \\
\text { relationship with your hypermarket } \\
\text { within the next one year? }\end{array}$ & $\begin{array}{l}0.881 \\
0.899 \\
\end{array}$ & 1.267 & 20.336 & 0.894 \\
\hline F3 & $\begin{array}{l}\text { Customer } \\
\text { Trust }\end{array}$ & $\begin{array}{l}\text { In our relationship, my hypermarket } \\
\text { cannot be trusted at times } \\
\text { In our relationship, my hypermarket } \\
\text { can be counted to do what is right } \\
\text { In our relationship, my hypermarket } \\
\text { has high integrity }\end{array}$ & $\begin{array}{l}0828 \\
0.802 \\
0.836\end{array}$ & 1.146 & 20.063 & 0.874 \\
\hline F4 & $\begin{array}{l}\text { Switching } \\
\text { Barrier }\end{array}$ & $\begin{array}{l}\text { Changing hypermarket is costly } \\
\text { Changing hypermarket requires a } \\
\text { lot of effort } \\
\text { I might have changed my } \\
\text { hypermarket if I could do so without } \\
\text { hassle }\end{array}$ & $\begin{array}{l}0.916 \\
0.874 \\
0.888\end{array}$ & 5.561 & 23.560 & 0.942 \\
\hline
\end{tabular}

Source: Developed for this research

Notes:

$\mathrm{KMO}=0.840$

Approx. Chi-Square $=1282.590$

d.f. $=66$

$\mathrm{P}$ value $=0.0001(<0.05)$

Rotation sums of Squared loadings $=85.022$

Sig $=0.000$ 
Table 4. Results of Multiple Regression Analysis for this Research

\begin{tabular}{|c|c|c|c|}
\hline Variables & $\begin{array}{c}\text { Unstandardized Beta } \\
\text { Coefficients }\end{array}$ & t-value & Significant \\
\hline Customer Satisfaction & 0.179 & 2.461 & $0.015(\mathrm{p}<0.05)$ \\
\hline Customer Trust & 0.397 & 4.165 & $0.0001(\mathrm{p}<0.05)$ \\
\hline Switching Barriers & 0.257 & 3.655 & $0.0001(\mathrm{p}<0.05)$ \\
\hline
\end{tabular}

\section{Notes:}

Dependent variable: customer retention

Independent variables: customer satisfaction, customer trust and switching barrier
$\mathrm{R}=62.3$ per cent
$\mathrm{R}$ Square $=38.8$ per cent
Adjusted R Square $=37.4$ per cent
$\mathrm{F}=28.293$
$\mathrm{P}=0.0001(\mathrm{p}<0.05)$

Table 5. Result of Simple Linear Regression Analysis for this research

\begin{tabular}{|c|c|c|c|}
\hline \multicolumn{4}{|c|}{ Coefficients } \\
\hline Variable & $\begin{array}{c}\text { Unstandardized } \\
\text { Coefficients B }\end{array}$ & $\begin{array}{c}\text { t- value } \\
\quad\end{array}$ & Significant \\
\hline $\begin{array}{l}\text { Customer } \\
\text { Satisfaction }\end{array}$ & 0.226 & 3.034 & $0.003(\mathrm{p}<0.05)$ \\
\hline
\end{tabular}

\section{Notes:}

Dependent variable: Customer Trust

Independent variable: Customer Satisfaction

$\mathrm{R}=25.2$ per cent $\quad \mathrm{R}$ Square $=6.3$ per cent $\quad$ Adjusted $\mathrm{R}$ Square $=5.6$ per cent

$\mathrm{F}=9.202$

$$
\mathrm{P}=0.003(\mathrm{p}<0.05)
$$

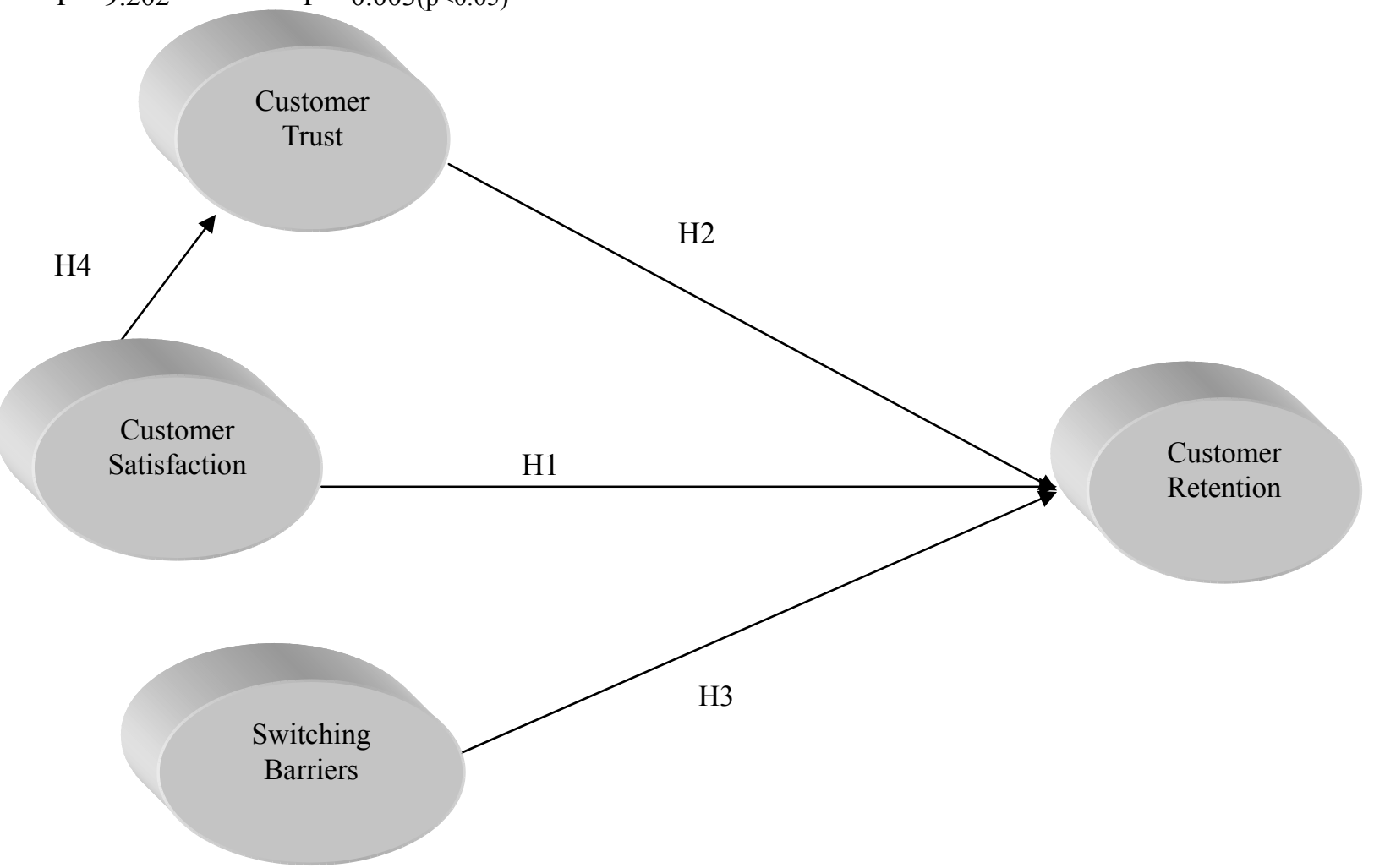

Figure 1. The Proposed Conceptual Framework for This Research

Source: Developed for this research 